\title{
Desorption Electrospray Ionization Imaging Mass Spectrometry of Lipids in Rat Spinal Cord
}

\author{
Marion Girod, ${ }^{\mathrm{a}}$ Yunzhou Shi, ${ }^{\mathrm{b}}$ Ji-Xin Cheng, ${ }^{\mathrm{b}}$ and R. Graham Cooks ${ }^{\mathrm{a}}$ \\ ${ }^{a}$ Department of Chemistry and Center for Analytical Instrumentation Development, Purdue University, \\ West Lafayette, Indiana, USA \\ ${ }^{\mathrm{b}}$ Weldon School of Biomedical Engineering, Purdue University, West Lafayette, Indiana, USA
}

Imaging mass spectrometry allows for the direct investigation of tissue samples to identify specific biological compounds and determine their spatial distributions. Desorption electrospray ionization (DESI) mass spectrometry has been used for the imaging and analysis of rat spinal cord cross sections. Glycerophospholipids and sphingolipids, as well as fatty acids, were detected in both the negative and positive ion modes and identified through tandem mass spectrometry (MS/MS) product ion scans using collision-induced dissociation and accurate mass measurements. Differences in the relative abundances of lipids and free fatty acids were present between white and gray matter areas in both the negative and positive ion modes. DESI-MS images of the corresponding ions allow the determination of their spatial distributions within a cross section of the rat spinal cord, by scanning the DESI probe across the entire sample surface. Glycerophospholipids and sphingolipids were mostly detected in the white matter, while the free fatty acids were present in the gray matter. These results show parallels with reported distributions of lipids in studies of rat brain. This suggests that the spatial intensity distribution reflects relative concentration differences of the lipid and fatty acid compounds in the spinal cord tissue. The "butterfly" shape of the gray matter in the spinal cord cross section was resolved in the corresponding ion images, indicating that a lateral resolution of better than $200 \mu \mathrm{m}$ was achieved. The selected ion images of lipids are directly correlated with anatomic features on the spinal cord corresponding to the white and the gray matter. (J Am Soc Mass Spectrom 2010, 21, 1177-1189) (c) 2010 Published by Elsevier Inc. on behalf of American Society for Mass Spectrometry

I ncreased recognition of the important functions of lipids in biological organisms [1, 2], coupled with the availability of new and more powerful analytical methods of characterizing compounds of this diverse class [3, 4], has propelled the rapid recent growth of the field of lipidomics [5-7]. The diverse functions of lipids include maintaining an electrochemical gradient, subcellular partitioning, cell signaling, energy storage, and membrane anchoring [2]. The most widely recognized role of lipids is to form the lipid bilayer of cellular and organelle membranes [8]. It has been reported that alterations in the glycerophospholipid composition of tissues occur in several diseases, including cancer [9] and Alzheimer's disease [10]. Particular glycerophospholipids and their enzymatic products have been identified in malignant transformations in tissue [11, 12]. In other cases, the expression of phosphatidylserine in the outer leaflet of the membrane has been found to play a role in the recognition of altered cells, such as cancer cells, by macrophages $[13,14]$. Lipids also play a role in atherosclerosis [15-17]. Indeed, the propensity of atherosclerotic plaques to rupture may be influenced by

Address reprint requests to Professor R. G. Cooks, Department of Chemistry, Purdue University, West Lafayette, IN 47907, USA. E-mail: cooks@ purdue.edu their lipid content and the distributions of these lipids within the plaque [18]. Differences in the content of specific lipids including cholesterol in plaque have been detected among the different types of plaque [19].

Lipids are the most common biomolecules found in the spinal cord and make up 50\% of its dry weight [20, 21]. The morphology of the spinal cord consists of white matter, the peripheral region containing sensor and myelinated axons, which surrounds the gray matter, composed primarily of neuronal cell bodies [21]. The spinal cord transmits neural signal between the peripheral nervous system and the brain and thus serves for the study of neuronal transmission, including neurological disability $[22,23]$. Understanding the nature of such complex biological processes in tissue requires identifying the specific compounds involved and determining where they are located in space and how they change in time. Information on some of these matters is available from studies on neurotransmitters using in situ microelectrodes [24,25], ultrafiltration followed by chromatography/mass spectrometry [26, 27], and other methods [28-30].

Imaging mass spectrometry (MS) has become an increasingly important tool for the study of complex biological systems, allowing one to record spatial and chemical information simultaneously for multiple ana- 
lytes over the sample area. Each pixel on the scanned surface yields a mass spectrum, which can then be compiled to create an image showing the spatial distribution of particular compounds [31,32]. Such an image can provide chemical correlations with biological function or morphology. The limitations of the approach are that it is highly invasive so time course information is difficult to obtain. Matrix-assisted laser desorption/ ionization (MALDI) and secondary ion mass spectrom- etry (SIMS) imaging have been used extensively. MALDI imaging is applicable to large molecules such as proteins [33-40] and peptides and can provide a spatial resolution of $100 \mu \mathrm{m}$ [39]; experiments are typically conducted under high vacuum and after application of an organic matrix to the sample to assist in ionization. Although the method has been primarily applied to proteins, MALDI has seen increasingly wide use in the investigation of distributions of lipids [41-

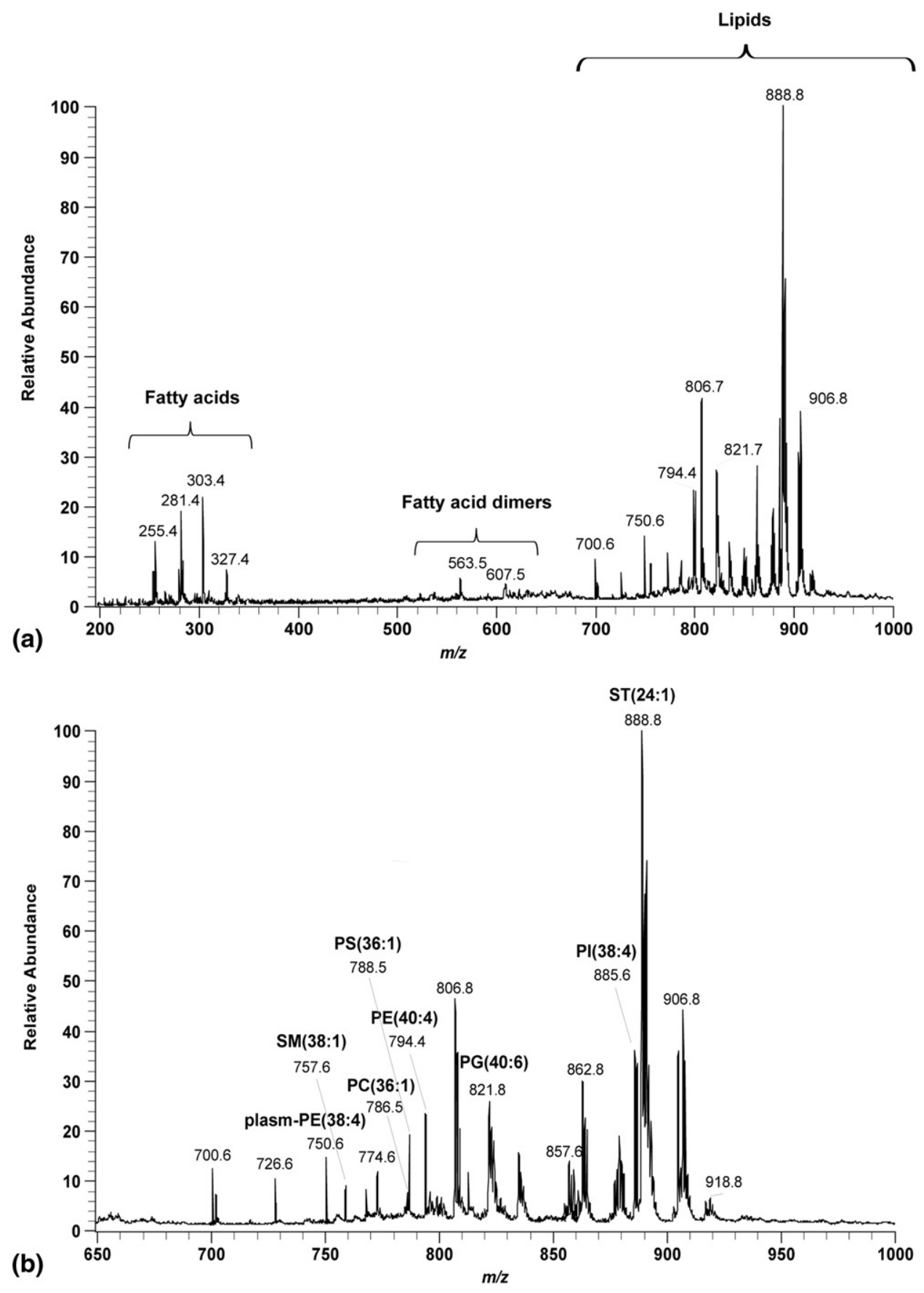

Figure 1. Negative ion DESI mass spectrum recorded on a $15 \mu \mathrm{m}$ thick rat spinal cord cross-section using $\mathrm{MeOH}$-water 70:30 (\% vol/vol) as the solvent spray. (a) Full mass spectrum. (b) Expanded view of the mass range from $\mathrm{m} / \mathrm{z} 650$ to 1000 , including the molecular ion, $[\mathrm{M}-\mathrm{H}]^{-}$, signals from several lipids. The most intense peaks for each class of lipids are annotated. 
48], drug molecules from tissue surfaces [49-54], and in a variety of other applications $[55,56]$. Imaging using SIMS potentially provides the advantage of very high spatial resolution of $\sim 100 \mathrm{~nm}$ and can be performed without additional sample preparation [51, 57-61]. However, SIMS imaging cannot be conducted under ambient conditions and is a harsher ionization technique that tends to produce more dissociation than MALDI. Desorption electrospray ionization (DESI) mass spectrometry [62] was introduced as a method for the direct analysis of biological samples, including tissue sections. DESI offers the advantage of little or no sample preparation as it does not require the addition of matrix compounds and is conducted at atmospheric pressure under ambient conditions [62]. Its disadvan- tages include a poorer spatial resolution than MALDI. It is one of a group of ambient ionization methods [63-65] amongst which the laser-based method of laser ablation electrospray ionization (LAESI) $[66,67]$ has given particularly useful images of biological systems, including in vivo systems. In DESI, a pneumatically-assisted electrospray produces charged droplets, which are directed at the surface of the sample, creating a thin liquid film which dissolves the analytes [68, 69]. The impact of subsequent primary droplets releases secondary microdroplets containing analytes [68, 69]. This so-called 'droplet pick-up' process is followed by the standard electrospray evaporation mechanisms which produce dry ions of the analytes [70, 71]. DESI has been used to construct chemical images of tissue sections [72-86] and<smiles>[R]C(=O)OCC(COP(=O)(O)OCC(N)C(=O)O)OC([R])=O</smiles>

1,2-diacyl glycerophosphoserine (PS)<smiles>[R]C(=O)OCC(COP(=O)(O)OCC(O)CO)OC([R])=O</smiles>

1,2-diacyl glycerophosphoglycerol (PG)<smiles>[R]C(=O)OCC(COP(=O)(O)OC1C(O)C2C(O)C(O)C(O)C1C2O)OC([R])=O</smiles>

1,2-diacyl glycerophosphoinositol (PI)<smiles>[R]C(=O)OCC(COP(=O)([O-])OCC[N+](C)(C)C)OC([R])=O</smiles>

2-diacyl glycerophosphocholine (PC)<smiles>[R16]C(=O)N[C@@H](COP(=O)([O-])OCC[N+](C)(C)C)[C@@H](O)/C=C/CCCCCCCCCCCCC</smiles><smiles>[R]C(=O)N[C@H](CO[C@H]1O[C@H](CO)[C@@H](O)[C@H](OS(=O)(=O)O)[C@H]1O)[C@@H](O)/C=C/CCCCCCCCCCCCC</smiles>

Scheme 1 
in forensic analysis $[87,88]$. The spatial resolution of DESI is typically $200 \mu \mathrm{m}$ [74] although significantly higher resolution has been reported [75].

This work presents a study of rat spinal cord tissue sections examined by DESI imaging mass spectrometry. Tissues sections were analyzed in both the negative and positive ion modes and tandem mass spectrometry (MS/MS) and exact mass measurements were used to identify the compounds detected. The major challenge to this application of DESI imaging mass spectrometry was the $4 \mathrm{~mm}$ size of the rat spinal cord section, which requires a high spatial resolution as reported in previous SIMS [89] and MALDI [90] imaging for spinal cord samples. The present aim was to establish if the distri- bution of lipids within rat spinal cord tissue sections could be determined and whether DESI lipid imaging mass spectrometry has the potential to serve as a tool for future detection of analyte changes in injured spinal cord samples.

\section{Experimental}

\section{Chemicals and Biological Samples}

Methanol $(\mathrm{MeOH})$ was purchased from Sigma-Aldrich (St. Louis, MO, USA), and water $(18.2 \mathrm{M} \Omega-\mathrm{cm})$ was from a PureLab Ultra system by Elga LabWater (High Wycombe, UK). Adult male Long-Evans rats (Hilltop
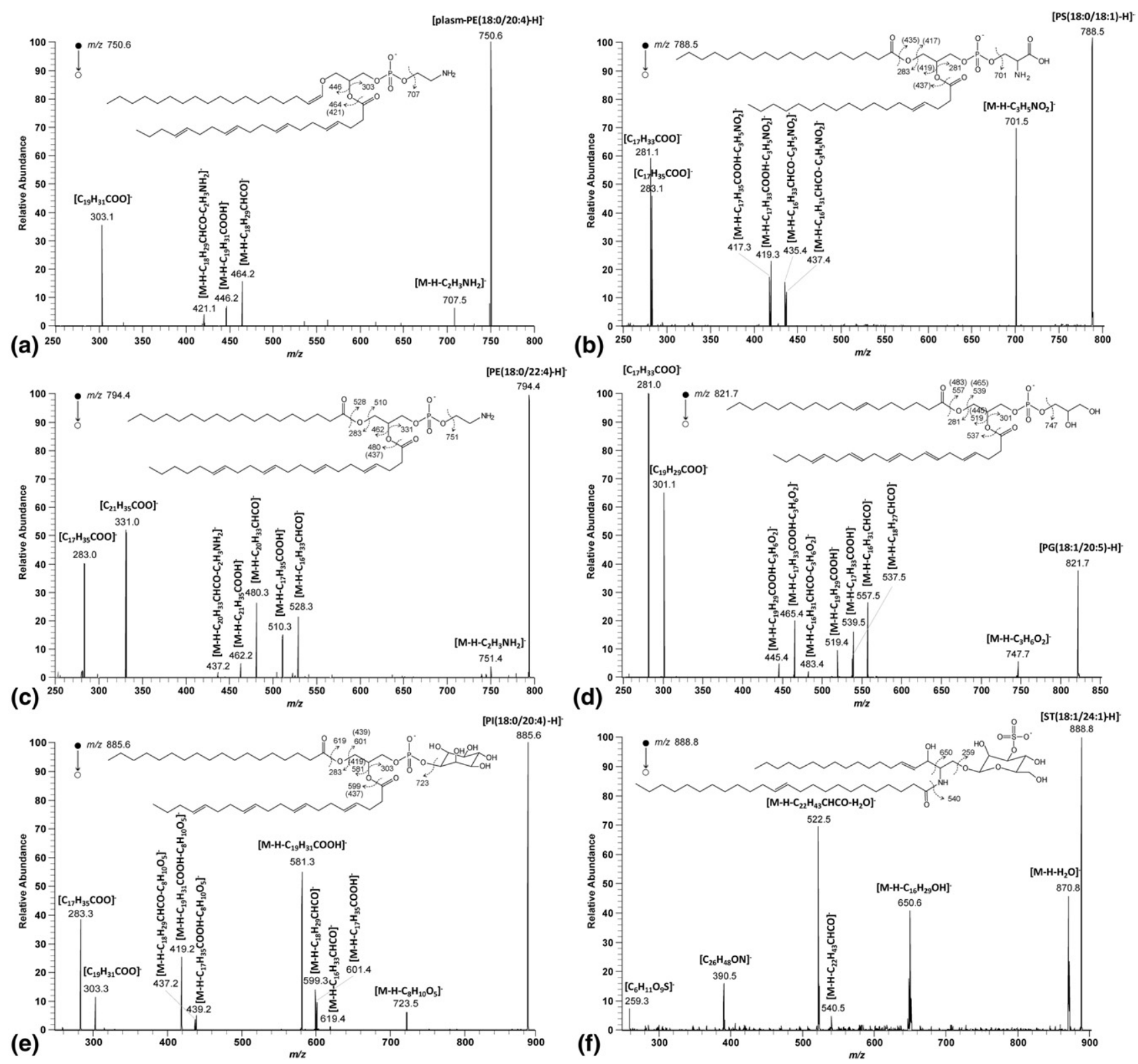

Figure 2. DESI-MS/MS spectra of (a) [plasm-PE(18:0/20:4) $-\mathrm{H}^{-}$, (b) $[\mathrm{PS}(18: 0 / 18: 1)-\mathrm{H}]^{-}$, (c) $[\mathrm{PE}(18: 0 / 22: 4)-\mathrm{H}]^{-}$, (d) $\left[\mathrm{PG}(18: 1 / 20: 5)-\mathrm{H}^{-}\right.$, (e) $[\mathrm{PI}(18: 0 / 20: 4)-\mathrm{H}]^{-}$, and (f) $[\mathrm{ST}(18: 1 / 24: 1)-$ $\mathrm{H}]^{-}$ions (collision energy: $25 \mathrm{eV}$, laboratory frame). Numbers in brackets correspond to the $\mathrm{m} / \mathrm{z}$ of the fragment ions produced consecutively after elimination of a portion of the head group. 
Lab Animals, Inc., Scottsdale, PA, USA) weighing 300$350 \mathrm{~g}$ were used.

\section{Tissue Preparation}

All protocols for this experiment were approved by the Purdue Animal Care and Use Committee. All rats were anesthetized deeply with a mixture of $90 \mathrm{mg} / \mathrm{kg}$ ketamine and $5 \mathrm{mg} / \mathrm{kg}$ xylazine and sacrificed by transcardial perfusion with cold PBS followed by $4 \%$ paraformaldehyde. The seventh thoracic (T7) spine was removed by laminectomy. The spinal tissue about $1 \mathrm{~cm}$ long was cryostat-sectioned at $15 \mu \mathrm{m}$ thickness and serially thaw-mounted on glass slides. The slices were dried in the air under room temperature for $2 \mathrm{~h}$, rehydrated in PBS solution for $15 \mathrm{~min}$, and washed once with PBS. Before imaging experiments, samples were dried under vacuum $15 \mathrm{~min}$.

\section{Mass Spectrometry}

DESI imaging analysis were performed with a commercial Thermo Scientific LTQ (San Jose, CA, USA) linear ion trap mass spectrometer equipped with a custombuilt, automated DESI source operated in both the negative and positive ion modes. The home-built DESI ion source is similar to the OmniSpray source from Prosolia Inc. (Indianapolis, IN, USA), configured as described previously [91]. A sprayer-to-surface distance of $2 \mathrm{~mm}$, a sprayer-to-inlet distance of $2.5 \mathrm{~mm}$, an incident angle to the horizontal of $52^{\circ}$ and a collection angle of $10^{\circ}$ were used. The spray voltage was set at $\pm 5000 \mathrm{~V}$ and the capillary voltage at $5 \mathrm{~V}$. Nitrogen gas was used as the nebulizing gas (140 psi). MeOH-water $70: 30(\% \mathrm{vol} / \mathrm{vol})$ was sprayed at a constant flow rate of $1.5 \mu \mathrm{L} / \mathrm{min}$. For the MS/MS experiments, a series of line scans across the tissue sample was performed during a period of about $1 \mathrm{~min}$. An isolation window of 1.5 mass / charge units, a normalized collision energy of $20 \%-40 \%$ (manufacturer's units) and a Mathieu parameter $q_{z}$ value of 0.25 during collisional activation were used. Exact mass measurements were performed using a commercial Thermo Scientific LTQ-Orbitrap XL mass spectrometer (Bremen, Germany), with the resolution set to 100,000 to confirm molecular formulae. Mass standards were added into the DESI spray at a concentration of $10 \mathrm{ppm}$. The $[\mathrm{M}-\mathrm{H}]^{-}$ion of taurocholate and $\mathrm{C}_{15} \mathrm{H}_{15} \mathrm{O}_{6} \mathrm{~N}_{3} \mathrm{P}_{3} \mathrm{~F}_{20}\left(\mathrm{C}_{2} \mathrm{~F}_{4}\right)_{2}$ Ultramark 1621 peak, with theoretical exact masses of 514.2839 and 1005.9727, respectively, were used as standards in the negative ion mode. The $[\mathrm{M}+\mathrm{H}]^{+}$ion of reserpine and the $[\mathrm{M}+$ $\mathrm{Na}]^{+}$ion of cyclosporine A, theoretical exact masses of 609.2812 and 1224.3311 , respectively, were used in the positive ion mode [92].

In the imaging experiments, the tissue was scanned using a 2D moving stage (Newport, Richmond, CA, USA) in horizontal rows separated by a $150 \mu \mathrm{m}$ vertical step until the entire tissue sample was analyzed [81]. The lines were scanned at a constant velocity of 132 $\mu \mathrm{m} / \mathrm{s}$, while collecting one mass spectrum every $1.16 \mathrm{~s}$ over the range $m / z 150-1000$. The ion injection time was set to $500 \mathrm{~ms}$ and 5 microscans were averaged. Under these conditions, a lateral spatial resolution of $\sim 200 \mu \mathrm{m}$ can be achieved in DESI MS imaging [74].

Xcalibur 2.0 software (Thermo Scientific LTQ, San Jose, CA, USA) was used for instrument control, data acquisition and data processing. Lab-written software was used to convert the Xcalibur mass spectra files (.raw) into a format compatible with BioMap. BioMap (freeware, http://www.maldi-msi.org/) was used to process the mass spectral data to generate twodimensional ion images.

Table 1. Molecular species detected from rat spinal cord tissue in negative ion mode

\begin{tabular}{|c|c|c|}
\hline$m / z$ & Molecular species ${ }^{a}$ & $\begin{array}{l}\text { Relative intensity in } \\
\text { spinal cord tissue } \\
\text { section }(\%)^{\text {b }}\end{array}$ \\
\hline 255.4 & Palmitic acid (16:0) & 18.2 \\
\hline 281.4 & Oleic acid (18:1) & 20.3 \\
\hline 283.4 & Stearic acid (18:0) & 16.8 \\
\hline 303.4 & Arachidonic acid (20:4) & 23.7 \\
\hline 327.4 & Docosahexaenoic acid (22:6) & 13.1 \\
\hline 563.5 & Dimer of oleic acid (18:1) & 5.6 \\
\hline 607.5 & Dimer of arachidonic acid $(20: 4)$ & 4.4 \\
\hline 700.6 & plasm-PE (34:1) & 13.2 \\
\hline 701.6 & SM $(34: 1)$ & 7.8 \\
\hline 726.6 & plasm-PE (36:2) & 11.9 \\
\hline 750.6 & plasm-PE (38:4) & 15.3 \\
\hline 757.6 & SM (38:1) & 8.7 \\
\hline 768.3 & PE (38:3) & 11.5 \\
\hline 774.6 & plasm-PE (40:6) & 12.6 \\
\hline 786.5 & $\mathrm{PC}(36: 1)$ & 6.4 \\
\hline 788.5 & PS $(36: 1)$ & 22.5 \\
\hline 794.4 & PE (40:4) & 24.1 \\
\hline 796.5 & PE (40:3) & 8.6 \\
\hline 806.7 & ST $(18: 0)$ & 46.3 \\
\hline 810.5 & PS (38:4) & 13.8 \\
\hline 821.7 & PG (40:6) & 26.4 \\
\hline 834.6 & PS (40:6) & 15.2 \\
\hline 857.6 & PI (36:4) & 16.3 \\
\hline 862.8 & ST $(22: 0)$ & 30.7 \\
\hline 878.8 & ST (h22:0) & 22.5 \\
\hline 885.6 & $\mathrm{PI}(38: 4)$ & 38.4 \\
\hline 888.8 & ST $(24: 1)$ & 100 \\
\hline 890.9 & ST $(24: 0)$ & 73.2 \\
\hline 904.8 & ST (h24:1) & 38.6 \\
\hline 906.8 & ST (h24:0) & 45.7 \\
\hline 916.7 & ST $(26: 1)$ & 8.5 \\
\hline 918.8 & ST $(26: 0)$ & 9.5 \\
\hline 932.7 & ST (h26:1) & 3.5 \\
\hline 934.7 & ST (h26:0) & 4.1 \\
\hline
\end{tabular}

All species are detected as deprotonated forms.

${ }^{a}(X: Y)$ represents the different number of carbon atoms and different number of double bonds in the fatty acid chains. The notation (hX:Y) denotes a hydroxylated sulfatide species.

belative intensities were calculated with respect to the base peak intensity. 


\section{Results and Discussion}

\section{Identification of Compounds}

Before the imaging experiments, the DESI experimental conditions were optimized to maximize the signal intensity obtained from the thin tissue sections in both the negative and positive ion modes. A series of line scans across the tissue sample was performed and the resulting mass spectra were examined.

The negative ion DESI mass spectrum from a rat spinal cord section is shown in Figure 1. In the low mass/charge region ( $\mathrm{m} / \mathrm{z} 200-400)$, ions corresponding to deprotonated free fatty acids are detected. These fatty acids can only be tentatively identified, since the possibility of isomers must be allowed. Based on the mass of the molecular anion, $m / z 255$ is a palmitic acid (16:0), $\mathrm{m} / \mathrm{z} 281$ is an oleic acid (18:1), $\mathrm{m} / \mathrm{z} 283$ is a stearic acid (18:0), $m / z 303$ is an arachidonic acid probably (20:4), and $m / z 327$ is a docosahexaenoic acid (22:6). The region from $m / z 500$ to $m / z 650$ includes dimers of the free fatty acids. In the high $m / z$ region $(m / z>600)$, ions corresponding to the deprotonated forms of various lipids are detected. Figure $1 \mathrm{~b}$ shows an expanded view of the DESI mass spectrum in the $m / z$ range $650-1000$. The lipid species detected from the rat spinal cord section mainly consist of sulfatides (ST), glycerophosphoserines (PS), glycerophosphoinositiols (PI), glycerophosphoethanolamines (PE) and plasmalogens (plasm$\mathrm{PE})$, glycerophosphoglycerols (PG) and, with a lower intensity, glycerophosphocholines (PC) and sphingomyelin (SM), as denoted in Figure $1 \mathrm{~b}$. Only the most intense peaks for each class of lipids have been annotated for better clarity. With a quaternary amine in the head group (Scheme 1), PC and SM ionize poorly in the negative ion mode (and well in the positive mode), while the polar PS, PG, PI, PE, and ST lipids ionize better in the negative ion mode $[93,94]$. Confirmation of the lipid assignments was achieved by tandem mass spectrometry (MS/MS) experiments (Figure 2), spectral comparisons with authentic lipid standards and comparisons to existing electrospray (ESI) mass spectra [94]. The molecular ion detected at $\mathrm{m} / \mathrm{z} 750.6$ has been identified as [plasm-PE(18:0/20:4) $-\mathrm{H}^{-}$based on its MS/MS behavior (Figure 2a). Loss of the ethanolamine portion of the head group (43 Da) from the precursor ion produces $\left[\mathrm{M}-\mathrm{H}-\mathrm{C}_{2} \mathrm{H}_{3} \mathrm{NH}_{2}\right]^{-}, m / z$ 707.5. The fragment ion detected at $m / z 464.2$, corresponding to $\left[\mathrm{M}-\mathrm{H}-\mathrm{C}_{18} \mathrm{H}_{29} \mathrm{CHCO}\right]^{-}$, would arise from the loss of the fatty acid chain at the $s n-2$ position as an alkyl ketene [95]. This reaction could also occur after the prior elimination of the ethanolamine portion of the head group (43 Da), yielding the ion detected at $\mathrm{m} / \mathrm{z} 421.1$, denoted $\left[\mathrm{M}-\mathrm{H}-\mathrm{C}_{18} \mathrm{H}_{29} \mathrm{CHCO}-\mathrm{C}_{2} \mathrm{H}_{3} \mathrm{NH}_{2}\right]^{-}$. The ion denoted $\left[\mathrm{M}-\mathrm{H}-\mathrm{C}_{19} \mathrm{H}_{31} \mathrm{COOH}\right]^{-}$, detected at $\mathrm{m} / \mathrm{z}$ 421.1 , could be the result of loss of the fatty acid chain at the sn-2 position while the carboxylate anion $\left[\mathrm{C}_{19} \mathrm{H}_{31} \mathrm{COO}\right]^{-}$from the $\mathrm{C} 20: 4$ fatty acid chain is detected at $\mathrm{m} / \mathrm{z} 303.1$ [95]. However, ions due to different compounds may still overlap. To minimize this possibility and separate likely isobaric lipids, high-resolution MS was performed by analyzing the tissues using DESI on the Orbitrap (see Figure S1 in the Supplementary Material). The results show that peak at $\mathrm{m} / \mathrm{z} 750.5411$ can be accurately assigned as having the exact mass of [plasm-PE(18:0/20:4) $-\mathrm{H}]^{-}$with an error of $-4.4 \mathrm{ppm}$. The ion detected at $m / z 788.5$ in the MS spectrum (Figure 1) has been identified as [PS(18:0/18:1) - H] ( $m / z$ 788.5463, error: +2.0 ppm on the DESI-Orbitrap). The MS/MS spectrum (Figure $2 b$ ) shows a predominant loss of $87 \mathrm{Da}$ from the precursor ion corresponding to

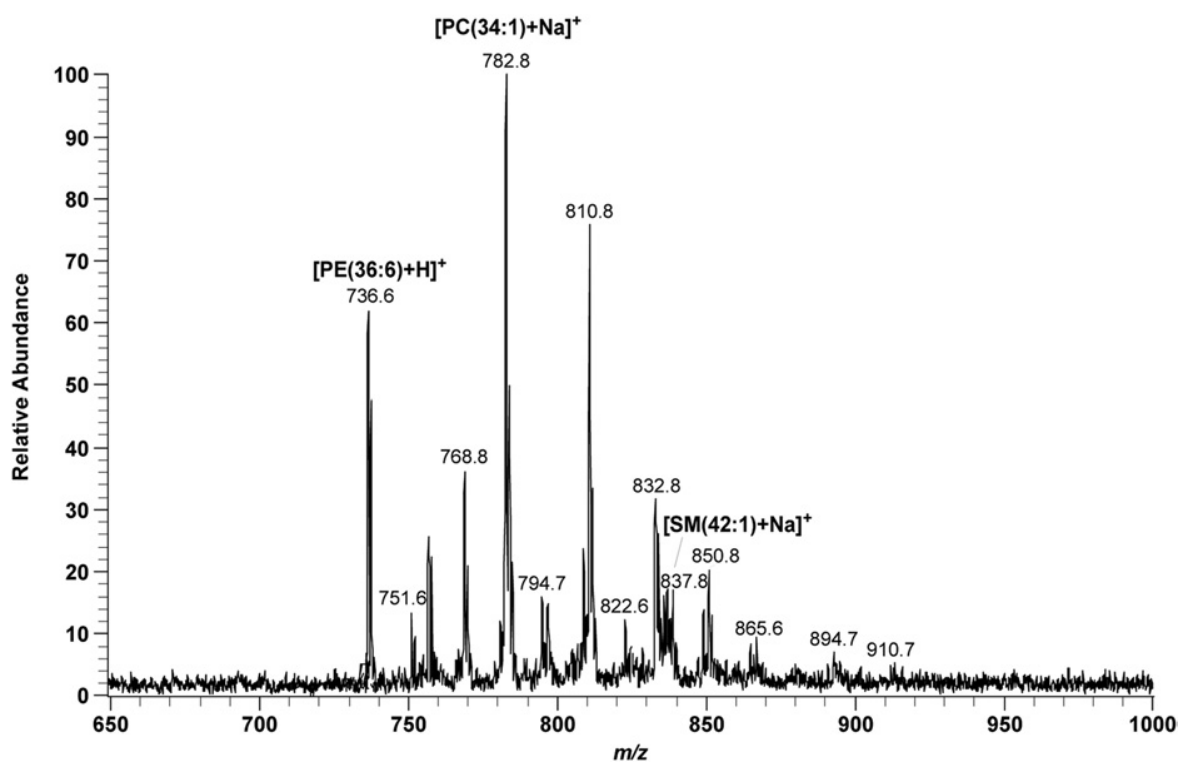

Figure 3. Expanded view of the mass range from $\mathrm{m} / \mathrm{z} 650$ to 1000 of the positive DESI mass spectrum recorded on a $15 \mu \mathrm{m}$ thick rat spinal cord cross-section using $\mathrm{MeOH}-w a t e r$ 70:30 (\% vol/vol) as the solvent spray. The most intense peaks for each class of lipids are annotated. 
the serine portion of the head group [93, 94], which would give rise to the $\left[\mathrm{M}-\mathrm{H}-\mathrm{C}_{3} \mathrm{H}_{5} \mathrm{NO}_{2}\right]^{-}$fragment ion detected at $m / z$ 701.5. The consecutive elimination as an alkyl ketene from the fatty acid chains at the $s n-1$ and $s n-2$ position from the $\left[\mathrm{M}-\mathrm{H}-\mathrm{C}_{3} \mathrm{H}_{5} \mathrm{NO}_{2}\right]^{-}$fragment ion are observed, as well as the consecutive elimination of the $\mathrm{C} 18: 0$ and $\mathrm{C} 18: 1$ fatty acid chains from the $[\mathrm{M}-\mathrm{H}$ $\left.-\mathrm{C}_{3} \mathrm{H}_{5} \mathrm{NO}_{2}\right]^{-}$fragment ion [93, 94]. Fatty carboxylic acid anions $\left(\left[\mathrm{C}_{17} \mathrm{H}_{35} \mathrm{COO}\right]^{-}\right.$and $\left.\left[\mathrm{C}_{17} \mathrm{H}_{33} \mathrm{COO}\right]^{-}\right)$are detected at $m / z 283.1$ and 281.1. Returning to the mass spectrum, the ion detected at $\mathrm{m} / \mathrm{z} 794.4$ has been identified as $[\mathrm{PE}(18: 0 / 22: 4)-\mathrm{H}]^{-}$on the basis of its accurate mass $(\mathrm{m} / \mathrm{z} 794.5685$, error: $-2.6 \mathrm{ppm}$ on the DESI-Orbitrap) and its MS/MS behavior (Figure 2c) [96, 97]. As the plasmalogen deprotonated species previously described, the precursor ion is expected to elim- inate the ethanolamine portion of the head group (43 $\mathrm{Da}$ ), yielding the ion detected at $\mathrm{m} / \mathrm{z} 751.4$, noted [M $\left.\mathrm{H}-\mathrm{C}_{2} \mathrm{H}_{3} \mathrm{NH}_{2}\right]^{-}$. Loss of fatty acid chain either at the $s n-1$ or $s n-2$ position from the precursor ion are also observed and corresponding fatty carboxylic acid anions are detected at $\mathrm{m} / \mathrm{z} 283.0$ and $\mathrm{m} / \mathrm{z}$ 331.0, respectively. The elimination as an alkyl ketene from one of the fatty acid chains at the $s n-1$ and $s n-2$ positions in the precursor ion or from the $\left[\mathrm{M}-\mathrm{H}-\mathrm{C}_{2} \mathrm{H}_{3} \mathrm{NH}_{2}\right]^{-}$ fragment ion complete this accounting of the observed fragmentation pathways. The MS/MS spectrum of the ion detected at $m / z 821.7(\mathrm{~m} / z$ 821.5368, error: $+3.5 \mathrm{ppm}$ on the DESI-Orbitrap) allows the anion to be identified as $[\mathrm{PG}(18: 1 / 20: 5)-\mathrm{H}]^{-}$(Figure 2d) [98-100]. The fragment ion $\left(\left[\mathrm{M}-\mathrm{H}-\mathrm{C}_{3} \mathrm{H}_{6} \mathrm{O}_{2}\right]^{-}\right.$) detected at $\mathrm{m} / \mathrm{z}$ 747.7 would arise from the elimination of the glycerol
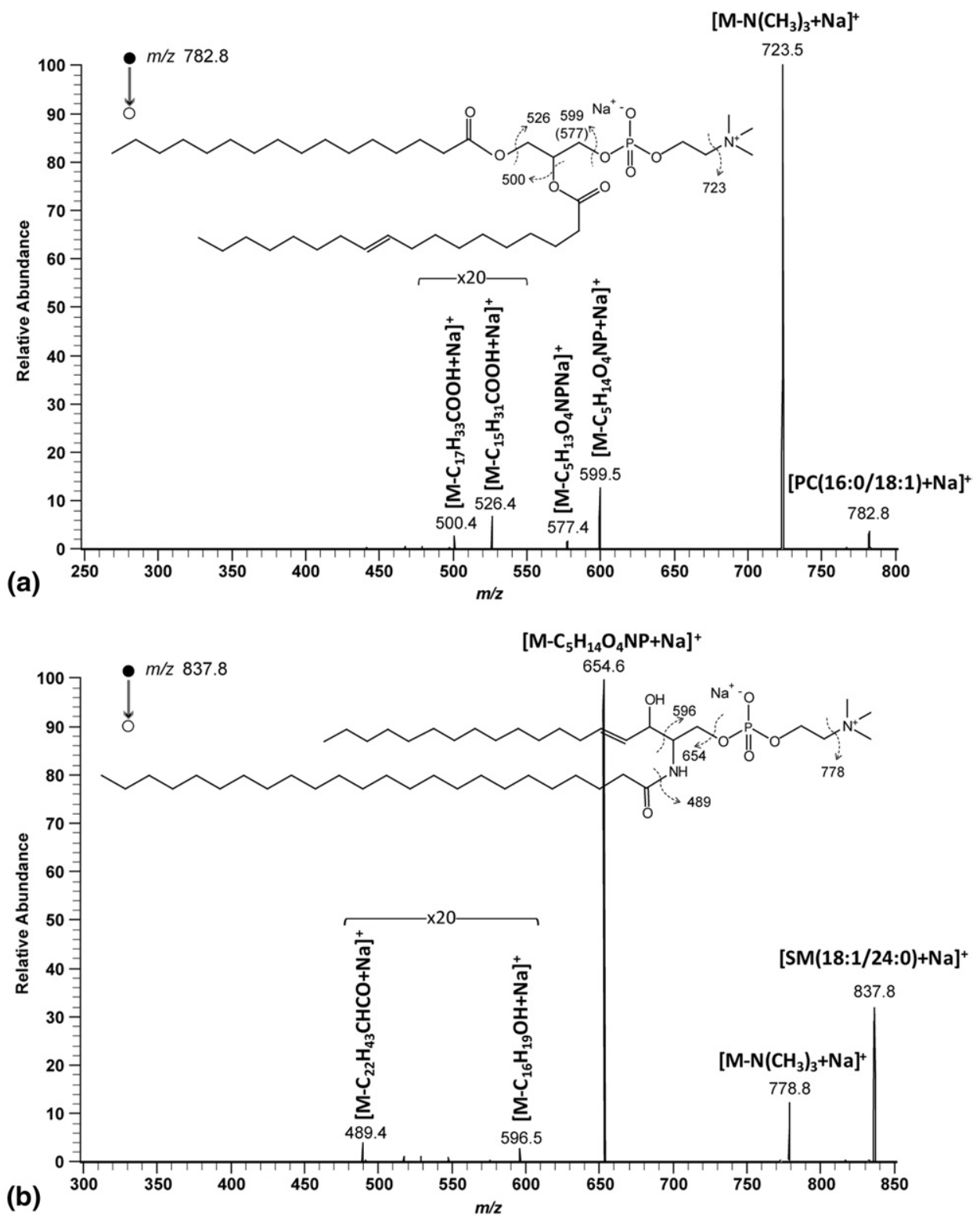

Figure 4. DESI-MS/MS spectra of (a) $[\mathrm{PC}(16: 0 / 18: 1)+\mathrm{Na}]^{+}$, and $(\mathbf{b})[\mathrm{SM}(18: 1 / 24: 0)+\mathrm{Na}]^{+}$ions (collision energy: $25 \mathrm{eV}$, laboratory frame). 
polar head group (74 Da) from the precursor ion. Thus, the elimination of the fatty acid chain either at the $s n-1$ or $s n-2$ position can occur from both the precursor ion and the $\left[\mathrm{M}-\mathrm{H}-\mathrm{C}_{3} \mathrm{H}_{6} \mathrm{O}_{2}\right]^{-}$ion. Fatty carboxylic acid ions $\left(\left[\mathrm{C}_{17} \mathrm{H}_{33} \mathrm{COO}\right]^{-}\right.$and $\left.\left[\mathrm{C}_{19} \mathrm{H}_{21} \mathrm{COO}\right]^{-}\right)$are detected at $m / z 281.0$ and $m / z$ 301.1. Loss of the C18:1 or the C20:5 chain as a ketene neutral also occurs from the precursor ion and from the $\left[\mathrm{M}-\mathrm{H}-\mathrm{C}_{3} \mathrm{H}_{6} \mathrm{O}_{2}\right]^{-}$fragment ion. The MS/MS spectrum of the ion detected at $\mathrm{m} / \mathrm{z} 885.6 \mathrm{(m} / \mathrm{z}$ 885.5514, error: +1.7 ppm on the DESI-Orbitrap) allows one to identify the anion as $[\mathrm{PI}(18: 0 / 20: 4)-\mathrm{H}]^{-}$(Figure 2e). The fragment ion ( $\left.\left[\mathrm{M}-\mathrm{H}-\mathrm{C}_{8} \mathrm{H}_{10} \mathrm{O}_{5}\right]^{-}\right)$detected at $\mathrm{m} / \mathrm{z} 723.5$ would arise from the elimination of the inositol head group (162 Da) from the precursor ion. Thus, this ion fragments to give three major series of product ions that are formed by neutral loss of free fatty acid, neutral loss of ketene and by formation of fatty carboxylate anions [101]. Sulfatides differ from the lipids discussed thus far in that they do not contain a glycerol-phosphate backbone but instead possess a sphingosine base (Scheme 1). Sulfatide fragmentation described in the literature shows several complex processes [93, 102, 103]. The collision induced dissociation of the $[\mathrm{ST}(18: 1 / 24: 1)-\mathrm{H}]^{-}$ion detected at $\mathrm{m} / \mathrm{z} 888.8$ $(\mathrm{m} / \mathrm{z}$ 888.6255, error: $+1.5 \mathrm{ppm}$ on the DESI-Orbitrap), gives rise to a peak at $m / z 522.5$ ([M - $\mathrm{H}-$ $\left.\mathrm{C}_{22} \mathrm{H}_{43} \mathrm{CHCO}-\mathrm{H}_{2} \mathrm{O}\right]^{-}$), which corresponds to the loss of water and the amide linked ketene by cleavage of the amine bond (Figure 2f). Loss of water molecule from the precursor ion is indicated by the product ion at $\mathrm{m} / \mathrm{z}$ $870.8\left(\left[\mathrm{M}-\mathrm{H}-\mathrm{H}_{2} \mathrm{O}\right]^{-}\right)$. The fragment of $\mathrm{m} / \mathrm{z} 390.5$ $\left(\left[\mathrm{C}_{26} \mathrm{H}_{48} \mathrm{ON}\right]^{-}\right)$would arise from the cleavage of the C2-C3 bond of the sphingosine backbone along with loss of the head group via cleavage of the $\mathrm{C} 1-\mathrm{O}$ bond. The fragment ion detected at $m / z$ 650.6 ([M - H $\left.\mathrm{C}_{16} \mathrm{H}_{29} \mathrm{OH}\right]^{-}$) appears to arise from loss of the longchain base after the second carbon. Loss of the chain as a ketene neutral at the $s n-2$ position from the precursor ion would give rise to the $\left[\mathrm{M}-\mathrm{H}-\mathrm{C}_{22} \mathrm{H}_{43} \mathrm{CHCO}^{-}\right.$ ion, detected at $m / z$ 540.5. Finally, the ion detected at $\mathrm{m} / \mathrm{z} 259.3$ corresponds to the polar head group anion $\left[\mathrm{C}_{6} \mathrm{H}_{11} \mathrm{O}_{9} \mathrm{~S}\right]^{-}$. All of the other peaks in the lipid profile of the spinal cord can likewise be identified based on their CID spectra. A summary of the peak assignments and the relative abundances in the whole spinal cord for negative ion $[\mathrm{M}-\mathrm{H}]^{-}$ions is given in Table 1 . These data are consistent with previously reported MS analysis of rat brain sections [45, 80, 89]. Although the sulfatide lipids are not the most abundant in rat spinal cord [21], they correspond to the main detected ions in the negative ion mass spectrum, their more efficient ionization being due to the high acidity of the sulfonic group.

In the positive ion mode, ions are detected in the high $m / z$ region with a lower signal/noise ratio than in negative mode, as shown in the expanded view of the DESI mass spectrum in the $\mathrm{m} / \mathrm{z}$ range 650-1000 (Figure $3)$. The major biomolecules detected are glycerophosphocholines (PC), sphingomyelin (SM), and glycero- phosphoethanolamines (PE), and plasmalogens (plasm$\mathrm{PE})$ as protonated $[\mathrm{M}+\mathrm{H}]^{+}$or sodiated $[\mathrm{M}+\mathrm{Na}]^{+}$ adducts. Only the most intense peaks for each class of lipids have been annotated for clarity, but the mass spectrum in Figure 3 is dominated by PC species. MS/MS experiments were also performed on the tissue samples and compared to published fragmentation [93, $94,104]$ to identify the lipids detected in the full scan mass spectra, as well as accurate mass measurements on the DESI-Orbitrap (see Figure S1 in the Supplementary Material). Indeed, based on its fragmentation behavior, the ion detected at $m / z 782.8$ in the MS spectrum $(\mathrm{m} / \mathrm{z}$ 782.5704, error: $+4.5 \mathrm{ppm}$ on the DESI-Orbitrap) has been identified as $[\mathrm{PC}(16: 0 / 18: 1)+\mathrm{Na}]^{+}$. Predominant loss of $59 \mathrm{Da}$, representing the $\left(\mathrm{CH}_{3}\right)_{3} \mathrm{~N}$ group [105-110], from the precursor ion is indicated by a product ion at $m / z 723.5\left(\left[\mathrm{M}-\left(\mathrm{CH}_{3}\right)_{3} \mathrm{~N}+\mathrm{Na}\right]^{+}\right)$as shown in the MS/MS spectrum (Figure 4a). Loss of the polar head group is also observed and gives rise to the sodiated adduct detected at $\mathrm{m} / \mathrm{z} 599.5$ ([M $\left.\left.\mathrm{C}_{5} \mathrm{H}_{14} \mathrm{O}_{4} \mathrm{NP}+\mathrm{Na}\right]^{+}\right)$. Additionally, the fragment cation detected at $m / z 577.4\left(\left[\mathrm{M}-\mathrm{C}_{5} \mathrm{H}_{13} \mathrm{O}_{4} \mathrm{NPNa}\right]^{+}\right)$would be expected to arise from the loss of the sodiated-complex of the polar head group (205 Da) from the precursor ion $[107,108]$. Two ions are detected at $\mathrm{m} / \mathrm{z} 500.4$ and 526.4 with low abundance and correspond to the loss of one of the two fatty acids (C16:0 and C18:1, respectively) from the precursor ion. Similarly, the peaks at $m / z 837.8$ ( $\mathrm{m} / \mathrm{z}$ 837.6767, error: -6.3 ppm using the DESI-Orbitrap) has been identified as $[\operatorname{SM}(18: 1 / 24: 0)+\mathrm{Na}]^{+}$. The MS/MS spectrum of this ion (Figure $4 \mathrm{~b}$ ) shows a

Table 2. Molecular species detected from rat spinal cord tissue in positive ion mode

\begin{tabular}{ccc}
\hline$m / z$ & $\begin{array}{c}\text { Molecular } \\
\text { species }^{\mathrm{a}}\end{array}$ & $\begin{array}{c}\text { Relative intensity in spinal } \\
\text { cord tissue section }(\%)^{\mathrm{b}}\end{array}$ \\
\hline \hline 736.6 & $\mathrm{PE}(36: 6)^{\mathrm{d}}$ & 63.4 \\
751.6 & $\mathrm{PC}(32: 3)^{\mathrm{c}}$ & 18.6 \\
756.6 & $\mathrm{PC}(32: 0)^{\mathrm{c}}$ & 28.4 \\
768.8 & $\mathrm{PE}(38: 4)^{\mathrm{d}}$ & 32.9 \\
782.8 & $\mathrm{PC}(34: 1)^{\mathrm{c}}$ & 100 \\
794.7 & $\mathrm{PE}(38: 2)^{\mathrm{c}}$ & 14.2 \\
796.7 & $\mathrm{PE}(38: 1)^{\mathrm{c}}$ & 16.9 \\
810.8 & $\mathrm{PC}(36: 1)^{\mathrm{c}}$ & 71.6 \\
822.6 & $\mathrm{PE}(40: 2)^{\mathrm{c}}$ & 11.5 \\
832.8 & $\mathrm{PC}(38: 4)^{\mathrm{c}}$ & 35.4 \\
836.8 & $\mathrm{PC}(38: 2)^{\mathrm{c}}$ & 15.2 \\
837.8 & $\mathrm{SM}(42: 1)^{\mathrm{c}}$ & 18.1 \\
846.7 & $\mathrm{PC}(40: 0)^{\mathrm{d}}$ & 9.7 \\
850.8 & $\mathrm{PC}(38: 3)^{\mathrm{e}}$ & 22.4 \\
865.6 & $\mathrm{SM}(44: 1)^{\mathrm{c}}$ & 7.5 \\
868.7 & $\mathrm{PC}(40: 1)^{\mathrm{c}}$ & 8.3 \\
894.7 & $\mathrm{PC}(42: 1)^{\mathrm{c}}$ & 4.1 \\
910.7 & $\mathrm{PE}(46: 0)^{\mathrm{c}}$ & 5.6 \\
\hline
\end{tabular}

${ }^{a}(X: Y)$ represents the different number of carbon atoms and different number of double bonds in the fatty acid chains.

${ }^{b}$ Relative intensities were calculated with respect to the base peak intensity.

'Species detected as sodiated adducts.

${ }^{\mathrm{d}}$ Species detected as protonated adducts.

eSpecies detected as potassiated adducts. 
neutral loss of $59 \mathrm{Da}$, which can be assigned to the loss of the $\left(\mathrm{CH}_{3}\right)_{3} \mathrm{~N}$ group from the precursor ion [111], yielding the fragment ion detected at $m / z$ 778.8, denoted $\left[\mathrm{M}-\left(\mathrm{CH}_{3}\right)_{3} \mathrm{~N}+\mathrm{Na}\right]^{+}$. The most abundant fragment ion detected at $m / z 654.6\left(\left[\mathrm{M}-\mathrm{C}_{5} \mathrm{H}_{14} \mathrm{O}_{4} \mathrm{NP}+\mathrm{Na}\right]^{+}\right)$ corresponds to the of the polar head group (183 Da) from the precursor ion [111]. In addition, very low abundance peaks at $m / z 596.5$ and $m / z 489.4$ are detected, corresponding, respectively, to the elimination of the long-chain base after the second carbon ([M $\left.\mathrm{C}_{16} \mathrm{H}_{19} \mathrm{O}_{4} \mathrm{H}+\mathrm{Na}\right]^{+}$) and the fatty acid chain as a ketene neutral $\left(\left[\mathrm{M}-\mathrm{C}_{22} \mathrm{H}_{43} \mathrm{CHCO}+\mathrm{Na}\right]^{+}\right)$from the precur- sor ion. All of the other peaks in the lipid profile of the spinal cord can likewise be identified based on their CID spectra. A summary of the peak assignments and the relative abundances in the whole spinal cord protonated $[\mathrm{M}+\mathrm{H}]^{+}$and sodiated $[\mathrm{M}+\mathrm{Na}]^{+}$adducts is given in Table 2.

Reported MS studies of rat brain tissues have also yielded strong mass peaks associated with PC in positive ion mode [43, 44, 93, 112]. Although glycerophosphocholines (PC) and glycerophosphoethanolamines (PE) have similar concentrations in rat spinal cords [21], the relative abundances of the PE species are weak
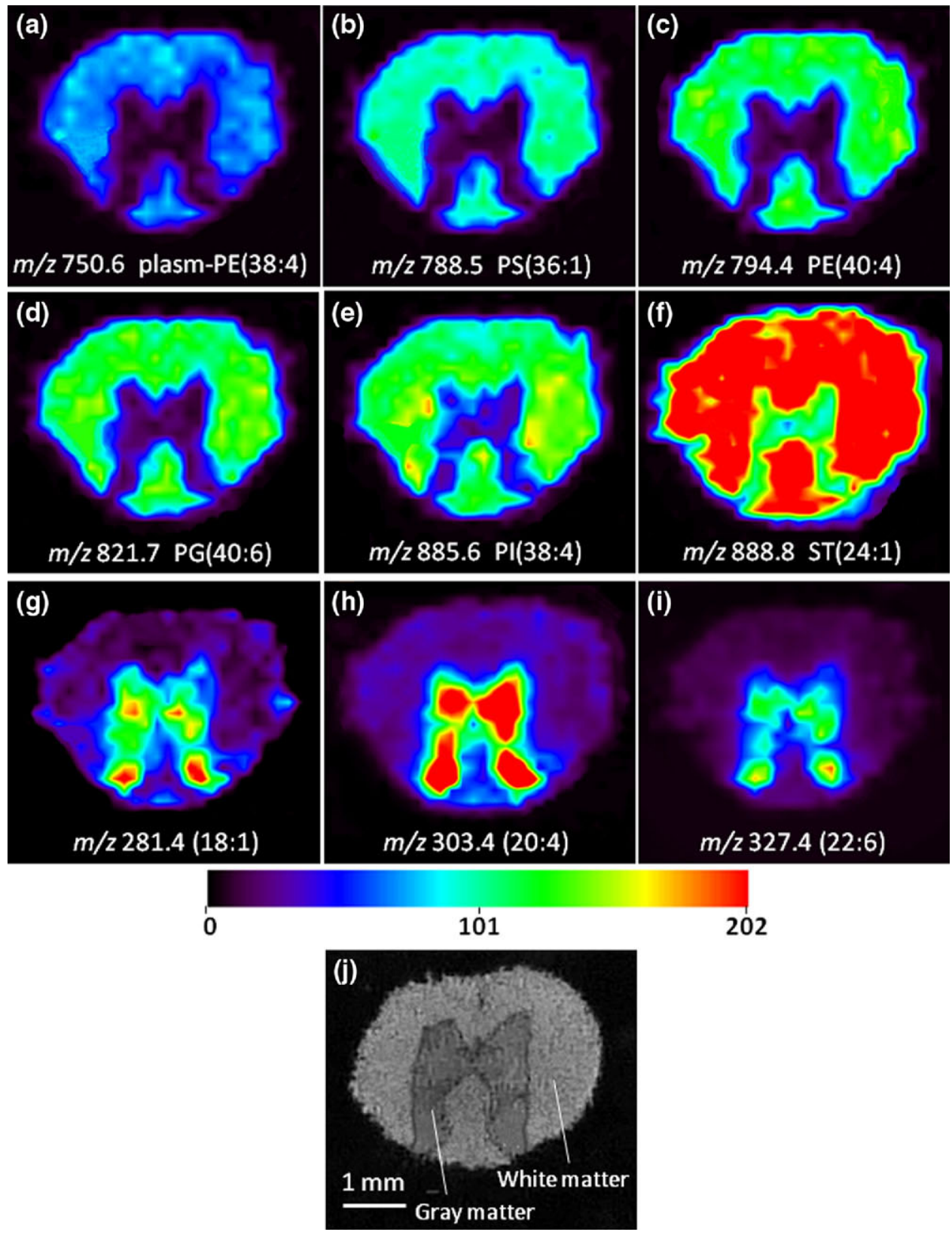

Figure 5. Selected molecular ion $[\mathrm{M}-\mathrm{H}]^{-}$images of specific lipids and fatty acids from analysis of a $3.8 \times 3.5 \mathrm{~mm}$ area of rat spinal cord cross section in the negative ion mode. Ion images of (a) plasm-PE(38:4), (b) PS(36:1), (c) PE(40:4), (d) PG(40:6), (e) PI(38:4), (f) ST(24:1), (g) (18:1), (h) (20:4), and (i) (22:6). (j) Optical image of the rat spinal cord cross-section. 
compared to PC in the positive mass spectra. Indeed, PC are characterized by the presence of a quaternary ammonium group whose positive charge is neutralized by the negative charge of the phosphate group (Scheme 1). Thus, $P C$ readily forms an abundant sodiated species when $\mathrm{Na}^{+}$ions are present in the sample because the phosphate anion can be easily sodiated during the DESI process in the positive ion mode. Furthermore, MS studies of standard phospholipid mixtures have shown that in positive ion mode PC and SM (both contain a quaternary ammonium group) suppress the detection of other phospholipid classes [113, 114].

\section{Tissue Imaging}

Tissue imaging experiments allow correlation of chemical information with morphological features of the sample. Rat spinal cord cross sections were imaged using DESI-MS in both the negative and the positive ion modes. Each image is a representation of the distribution of ions of one particular $\mathrm{m} / \mathrm{z}$ value and hence a representation of the distribution of the corresponding molecule in the tissue sample. Note that the peak intensity does not exactly represent molecular concentrations in the tissue due to the differences in ionization efficiency, competitive suppression effects or differences in the degree of fragmentation. However, for the same molecule in the same tissue type or closely related compounds in the same tissue, relative peak intensities should approximately reflect differences in intrinsic concentrations. This is a standard assumption in imaging studies and it has been discussed and justified in previous papers $[72,85,86]$.

The spatial images of specific lipids and fatty acids in the $3.8 \times 3.5 \mathrm{~mm}$ area of rat spinal cord cross section in the negative ion mode are shown in Figure 5. For comparison, an optical image is provided in Figure 5j and structural features (white and gray matter) are indicated. Each selected ion image is plotted on the same color scale to allow comparison of ion intensity between images. Ion images show a particular localization in either the white matter (light peripheral region in Figure 5j), which predominantly contains myelinated axons, or gray matter (dark central region in Figure 5j), which predominantly contains the cellular bodies. The image of the ion detected at $\mathrm{m} / \mathrm{z} 750.6$, identified as the deprotonated form of plasm-PE(38:4), shows an approximately homogeneous distribution in the area of the spinal cord corresponding to the white matter but much lower signals in the area corresponding to the gray matter (Figure 5a). A similar spatial intensity distribution with even more contrast is observed for the deprotonated PE(40:4) detected at $m / z 794.4$ (Figure 5c). PS, PG, PI, and ST lipids (Figure 5b-f) are also mainly located in the area corresponding to the white matter with less abundance in the gray matter. Figure 6 shows the spatial images of PC(36:1) and SM(42:1) lipids in the rat spinal cord cross section in the positive ion mode. Due to the low signal/noise ratio, the quality of the images is not as good as in the negative ion mode. Indeed, the lower signal intensity of the detected lipids (maximum at 80 arbitrary units in positive mode instead of 202 in the negative mode) results in a lower contrast between the spinal cord tissue and the other part of the scanned surface. However, positive ion mode images show the same particular localization in the white matter and support the interpretations made from the negative ion data. Signals at $m / z 782.5$ (Figure 6a) and $\mathrm{m} / \mathrm{z} 837.8$ (Figure 6b), which correspond to sodiated adducts of $\mathrm{PC}(34: 1)$ and $\mathrm{SM}(42: 1)$, are more intense in the white matter. In contrast, the complementary localization of ion images is observed for the fatty
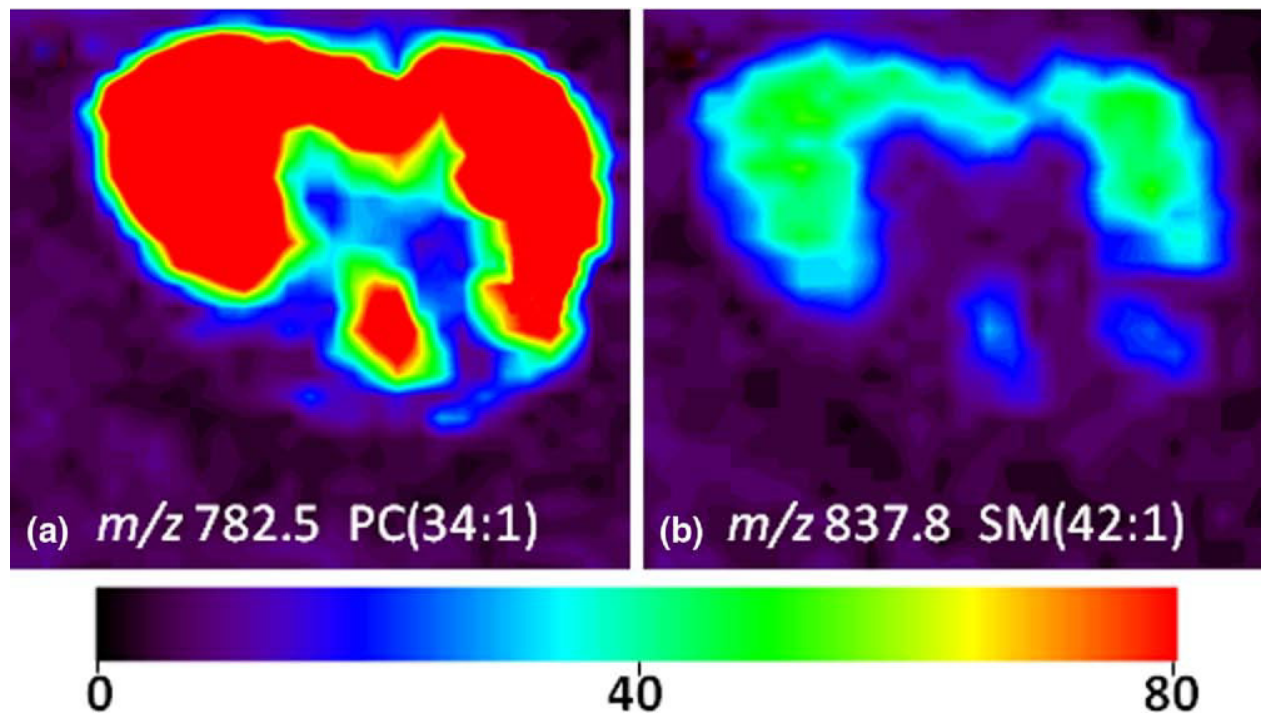

Figure 6. Selected molecular ion $[\mathrm{M}+\mathrm{Na}]^{+}$images of specific lipids from analysis of a $3.8 \times 3.5 \mathrm{~mm}$ area of rat spinal cord cross-section in the positive ion mode. Ion images of (a) $\mathrm{PC}(34: 1)$ and (b) $\operatorname{SM}(42: 1)$. 
acids, Figure $5 \mathrm{~g}-\mathrm{i}$. Indeed, the intensity of the signal detected at $m / z$ 281.4, identified as the deprotonated form of oleic acid (Figure $5 \mathrm{~g}$ ) is higher in the region of the spinal cord corresponding to the gray matter, as is that for arachidonic acid ( $\mathrm{m} / \mathrm{z}$ 303.4; Figure 5h) and docosahexaenoic acid $(\mathrm{m} / \mathrm{z}$ 327.4; Figure 5i).

These results agree with the reported studies of rat brains whereby lipids ions were associated with the myelinated axons (white matter) [20,21], while the fatty acids were present in the region enriched in neuronal cell bodies (gray matter) [80,115]. This suggests that the spatial intensity distribution reflects relative concentration differences of the lipid and fatty acid compounds in the spinal cord tissue. The "butterfly" shape of the gray matter in the spinal cord cross-section is resolved in the corresponding ion images, indicating that a lateral resolution of less than $200 \mu \mathrm{m}$ is achieved. The selected ion images of lipids are directly correlated with anatomic features on the spinal cord corresponding to the white and the gray matter.

\section{Conclusion}

This study has established that DESI imaging MS is a powerful tool for measuring lipid profiles in rat spinal cord with a spatial resolution less than $200 \mu \mathrm{m}$. The resulting ion images reflect the relative concentrations of the species detected from the tissue surface. DESI imaging MS presents advantages in terms of easy implementation and ambient analysis. MS/MS experiments have also been performed to confirm the identities of individual compounds. All these chemical and spatial information may help to a better understanding of lipid biochemistry within the spinal cord. This work presents the fundamental information needed to pursue future studies of spinal cord injury recovery processes. Indeed, DESI imaging technique will be used in future studies to determine the spatial distribution and expression levels of analytes and their changes during the injury recovery process and to evaluate the effects of drug treatment.

\section{Acknowledgments}

The authors acknowledge support for this work by the U.S. National Institutes of Health (grant 1R21EB009459-01).

\section{Appendix A Supplementary Material}

Supplementary material associated with this article may be found in the online version at doi:10.1016/ j.jasms.2010.03.028.

\section{References}

1. Oresic, M.; Hanninen, V. A.; Vidal-Puig, A. Lipidomics: A New Window to Biomedical Frontiers. Trends Biotechnol. 2008, 26, 647-652.

2. Watson, A. D. Lipidomics: A Global Approach to Lipid Analysis in Biological Systems. J. Lipid Res. 2006, 47, 2101-2111.
3. Niemela, P. S.; Castillo, S.; Sysi-Aho, M.; Oresic, M. Bioinformatics and Computational Methods for Lipidomics. J. Chromatogr. B Anal. Technol. Biomed. Life Sci. 2009, 877, 2855-2862.

4. Haimi, P.; Chaithanya, K.; Kainu, V.; Hermansson, M.; Somerharju, P. Instrument-Independent Software Tools for the Analysis of MS-MS and LC-Ms Lipidomics Data. Methods Mol. Biol. 2009, 580, 285-294.

5. German, J. B.; Gillies, L. A.; Smilowitz, J. T.; Zivkovic, A. M.; Watkins, S. M. Lipidomics and Lipid Profiling in Metabolomics. Curr. Opin. Lipidol. 2007, 18, 66-71.

6. Seppanen-Laakso, T.; Oresic, M. How to Study Lipidomes. J. Mol. Endocrinol. 2009, 42, 185-190.

7. Zhu, C.; Hu, P.; Liang, Q. L.; Wang, Y. M.; Luo, G. A. Recent Advances in Lipidomics. Chin J. Anal. Chem. 2009, 37, 1390-1396.

8. Vance, D. E.; Vance, J. E. In Biochemistry of Lipids, Lipoproteins and Membranes; Elsevier: New York, NY, 2002; pp 1-35.

9. Sakai, K.; Okuyama, H.; Yura, J.; Takeyama, H.; Shinagawa, N. Tsuruga, N.; Kato, K.; Miura, K.; Kawase, K.; Tsujimura, T.; Naruse, T. Koike, A. Composition and Turnover of Phospholipids and Neutral Lipids in Human Breast-Cancer and Reference Tissues. Carcinogenesis 1992, 13, 579-584.

10. Montine, T. J.; Neely, M. D.; Quinn, J. F.; Beal, M. F.; Markesbery W. R.; Roberts, L. J.; Morrow, J. D. Lipid Peroxidation in Aging Brain and Alzheimer's Disease. Free Radical Biol. Med. 2002, 33, 620-626.

11. Glunde, K.; Jie, C.; Bhujwalla, Z. M. Molecular Causes of the Aberrant Choline Phospholipid Metabolism in Breast Cancer. Cancer Res. 2004, $64,4270-4276$

12. Aboagye, E. O.; Bhujwalla, Z. M. Malignant Transformation Alters Membrane Choline Phospholipid Metabolism of Human Mammary Epithelial Cells. Cancer Res. 1999, 59, 80-84.

13. Zwaal, R. F. A.; Comfurius, P.; Bevers, E. M. Surface Exposure of Phosphatidylserine in Pathological Cells. Cell. Mol. Life Sci. 2005, 62, 971-988.

14. Utsugi, T.; Schroit, A. J.; Connor, J.; Bucana, C. D.; Fidler, I. J. Elevated Expression of Phosphatidylserine in the Outer-Membrane Leaflet of Human Tumor-Cells and Recognition by Activated Human Blood Monocytes. Cancer Res. 1991, 51, 3062-3066.

15. Morrow, J. D. Quantification of Isoprostanes as Indices of Oxidant Stress and the Risk of Atherosclerosis in Humans. Arterioscler. Thromb. Vascular Biol. 2005, 25, 279-286.

16. Polidori, M. C.; Pratico, D.; Savino, K.; Rokach, J.; Stahl, W.; Mecocci, $\mathrm{P}$. Increased F-2 Isoprostane Plasma Levels in Patients with Congestive Heart Failure are Correlated with Antioxidant Status and Disease Severity. J. Cardiovac. Fail. 2004, 10, 334-338.

17. Pratico, D.; Iuliano, L.; Mauriello, A.; Spagnoli, L.; Lawson, J. A. Maclouf, J.; Violi, F.; Fitzgerald, G. A. Localization of Distinct F-2Isoprostanes in Human Atherosclerotic Lesions. J. Clin. Invest. 1997, 100, 2028-2034

18. Ross, R. Mechanisms of Disease-Atherosclerosis-an Inflammatory Disease. N. Engl. J. Med. 1999, 340, 115-126.

19. Marinello, E.; Setacci, C.; Giubbolini, M.; Cinci, G.; Frosi, B.; Porcelli, B. Terzuoli, L. Lipid Composition in Atheromatous Plaque: Evaluation of the Lipid Three-Phase Percentage. Life Sci. 2003, 72, 2689-2694.

20. Agranoff, B. W.; Binjamins, J. A.; Hajra, A. K. In Basic Neurochemistry: Molecular, Cellular, and Medical Aspects, 6th ed.; Lippincott Williams \& Wilkins: Philadelphia, PA, 1999; pp 47-95.

21. Morell, P.; Quarles, R. H.; Norton, W. T. In Basic Neurochemistry: Molecular, Cellular, and Medical Aspects, 5th ed.; Raven Press, Ltd.: New York, NY, 1994; pp 117-143.

22. Lazzarini, R. In Myelin Biology and Its Disorders; Elsevier Academic Press: San Diego, CA, 2004; pp 1-53.

23. Waxman, S. G. Demyelinating Diseases-New Pathological Insights, New Therapeutic Targets. N. Engl. J. Med. 1998, 338, 323-325.

24. Heien, M.; Johnson, M. A.; Wightman, R. M. Resolving Neurotransmitters Detected by Fast-Scan Cyclic Voltammetry. Anal. Chem. 2004, 76, 5697-5704.

25. Troyer, K. P.; Heien, M.; Venton, B. J.; Wightman, R. M. Neurochemistry and Electroanalytical Probes. Curr. Opin. Chem. Biol. 2002, 6, 696-703.

26. Lanckmans, K.; Sarre, S.; Smolders, I.; Michotte, Y. Quantitative Liquid Chromatography/Mass Spectrometry for the Analysis of Microdialysates. Talanta 2008, 74, 458-469.

27. Zhang, X.; Rauch, A.; Xiao, H.; Rainer, G.; Logothetis, N. K. Mass Spectrometry-Based Neurochemical Analysis: Perspectives for Primate Research. Expert Rev. Proteom. 2008, 5, 641-652.

28. Perry, M.; Li, Q.; Kennedy, R. T. Review of Recent Advances in Analytical Techniques for the Determination of Neurotransmitters. Anal. Chim. Acta 2009, 653, 1-22.

29. Xu, M.; Basile, F.; Voorhees, K. J. Differentiation and Classification of User-Specified Bacterial Groups by in Situ Thermal Hydrolysis and Methylation of Whole Bacterial Cells with Tert-Butyl Bromide Chemical Ionization Ion Trap Mass Spectrometry. Anal. Chim. Acta 2000, 418, 119-128.

30. Basile, F.; Beverly, M. B.; Abbas-Hawks, C.; Mowry, C. D.; Voorhees, K. J.; Hadfield, T. L. Direct Mass Spectrometric Analysis of In Situ Thermally Hydrolyzed and Methylated Lipids from Whole Bacterial Cells. Anal. Chem. 1998, 70, 1555-1562.

31. Mcdonnell, L. A.; Heeren, R. M. A. Imaging Mass Spectrometry. Mass Spectrom. Rev. 2007, 26, 606-643.

32. Pacholski, M. L.; Winograd, N. Imaging with Mass Spectrometry. Chem. Rev. 1999, 99, 2977-3006. 
33. Andersson, M.; Groseclose, M. R.; Deutch, A. Y.; Caprioli, R. M. Imaging Mass Spectrometry of Proteins and Peptides: Vol III, Reconstruction. Nat. Methods 2008, 5, 101-108.

34. Burnum, K. E.; Frappier, S. L.; Caprioli, R. M. Matrix-Assisted Laser Desorption/Ionization Imaging Mass Spectrometry for the Investigation of Proteins and Peptides. Ann. Rev. Anal. Chem. 2008, 1, 689-705.

35. Caprioli, R. M. Perspectives on Imaging Mass Spectrometry in Biology and Medicine. Proteomics 2008, 8, 3679-3680

36. Caprioli, R. M.; Farmer, T. B.; Gile, J. Molecular Imaging of Biological Samples: Localization of Peptides and Proteins Using MALDI-TOF MS. Anal. Chem. 1997, 69, 4751-4760.

37. Chaurand, P.; Sanders, M. E.; Jensen, R. A.; Caprioli, R. M. Proteomics in Diagnostic Pathology-Profiling and Imaging Proteins Directly in Tissue Sections. Am. J. Pathol. 2004, 165, 1057-1068.

38. Chaurand, P.; Schwartz, S. A.; Caprioli, R. M. Profiling and Imaging Proteins in Tissue Sections by Ms. Anal. Chem. 2004, 76, 86A-93A.

39. Stoeckli, M.; Chaurand, P.; Hallahan, D. E.; Caprioli, R. M. Imaging Mass Spectrometry: A New Technology for the Analysis of Protein Expression in Mammalian Tissues. Nat. Med. 2001, 7, 493-496.

40. Seeley, E. H.; Caprioli, R. M. Molecular Imaging of Proteins in Tissues by Mass Spectrometry. Proc. Natl. Acad. Sci. U.S.A. 2008, 105, 1812618131.

41. Jackson, S. N.; Ugarov, M.; Egan, T.; Post, J. D.; Langlais, D.; Schultz, J. A.; Woods, A. S. MALDI-Ion Mobility-TOF-MS Imaging of Lipids in Rat Brain Tissue. J. Mass Spectrom. 2007, 42, 1093-1098.

42. Jackson, S. N.; Wang, H. Y. J.; Woods, A. S. Direct Tissue Analysis of Phospholipids in Rat Brain Using MALDI-TOF-MS and MALDI-Ion Mobility-TOF-MS. J. Am. Soc. Mass Spectrom. 2005, 16, 133-138.

43. Jackson, S. N.; Wang, H. Y. J.; Woods, A. S. In Situ Structural Characterization of Phosphatidylcholines in Brain Tissue Using MALDI-MS/MS. I. Am. Soc. Mass Spectrom. 2005, 16, 2052-2056.

44. Jackson, S. N.; Wang, H. Y. J.; Woods, A. S. Direct Profiling of Lipid Distribution in Brain Tissue Using MALDI-TOF-MS. Anal. Chem. 2005, $77,4523-4527$

45. Jackson, S. N.; Woods, A. S. Direct Profiling of Tissue Lipids by MALDI-TOF-MS. J. Chromatogr. B Anal. Technol. Biomed. Life Sci. 2009, $877,2822-2829$

46. Roy, S.; Touboul, D.; Brunelle, A.; Germain, D. P.; Laprevote, O.; Chaminade, P. Imaging Mass Spectrometry and Direct Analysis of Globotriaosylceramide and Galabiosylceramide in Tissue. MS Med. Sci. 2005, 21, 55-56.

47. Sjovall, P.; Lausmaa, J.; Johansson, B. Mass Spectrometric Imaging of Lipids in Brain Tissue. Anal. Chem. 2004, 76, 4271-4278.

48. Puolitaival, S. M.; Burnum, K. E.; Cornett, D. S.; Caprioli, R. M. Solvent-Free Matrix Dry-Coating for MALDI Imaging of Phospholipids. J. Am. Soc. Mass Spectrom. 2008, 19, 882-886.

49. Hsieh, Y.; Casale, R.; Fukuda, E.; Chen, J. W.; Knemeyer, I.; Wingate, J.; Morrison, R.; Korfmacher, W. Matrix-Assisted Laser Desorption/ Ionization Imaging Mass Spectrometry for Direct Measurement of Clozapine in Rat Brain Tissue. Rapid Commun. Mass Spectrom. 2006, 20, 965-972.

50. Sebastian, M.; Touboul, D.; Brunelle, A.; Laprevote, O.; Egido, J.; Vivanco, F. Metabolic Imaging Mass Spectrometry in Atherosclerotic Vessels. Mol. Cell. Proteom. 2005, 4, S163-S163.

51. Sjovall, P.; Johansson, B.; Belazi, D.; Stenvinkel, P.; Lindholm, B.; Lausmaa, J.; Schalling, M. TOF-SIMS Analysis of Adipose Tissue from Patients with Chronic Kidney Disease. Appl. Surf. Sci. 2008, 255, 1177-1180.

52. Stoeckli, M.; Staab, D.; Schweitzer, A. Compound and Metabolite Distribution Measured by MALDI Mass Spectrometric Imaging in Whole-Body Tissue Sections. Int. I. Mass Spectrom. 2007, 260, 195-202.

53. Wang, H. Y. J.; Jackson, S. N.; Woods, A. S. Direct MALDI-MS Analysis of Cardiolipin from Rat Organs Sections. J. Am. Soc. Mass Spectrom. 2007, 18, 567-577.

54. Wolstenholme, R.; Bradshaw, R.; Clench, M. R.; Francese, S. Study of Latent Fingermarks by Matrix-Assisted Laser Desorption/Ionization Mass Spectrometry Imaging of Endogenous Lipids. Rapid Commun. Mass Spectrom. 2009, 23, 3031-3039.

55. Francese, S.; Dani, F. R.; Traldi, P.; Mastrobuoni, G.; Pieraccini, G.; Moneti, G. MALDI Mass Spectrometry Imaging, from Its Origins up to Today: The State of the Art. Combinat. Chem. High Throughput Screen. 2009, 12, 156-174.

56. Franck, J.; Arafah, K.; Elayed, M.; Bonnel, D.; Vergara, D.; Jacquet, A.; Vinatier, D.; Wisztorski, M.; Day, R.; Fournier, I.; Salzet, M. Maldi Imaging Mass Spectrometry. Mol. Cell. Proteom. 2009, 8, 2023-2033.

57. Brunelle, A.; Touboul, D.; Laprevote, O. Biological Tissue Imaging with Time-of-Flight Secondary Ion Mass Spectrometry and Cluster Ion Sources. J. Mass Spectrom. 2005, 40, 985-999.

58. Magnusson, Y.; Friberg, P.; Sjovall, P.; Dangardt, F.; Malmberg, P.; Chen, Y. Lipid Imaging of Human Skeletal Muscle Using TOF-SIMS with Bismuth Cluster Ion as a Primary Ion Source. Clin. Physiol. Funct. Imaging 2008, 28, 202-209.

59. Todd, P. J.; Schaaff, T. G.; Chaurand, P.; Caprioli, R. M. Organic Ion Imaging of Biological Tissue with Secondary Ion Mass Spectrometry and Matrix-Assisted Laser Desorption/Ionization. J. Mass Spectrom. 2001, 36, 355-369.

60. Touboul, D.; Brunelle, A.; Halgand, F.; De La Porte, S.; Laprevote, O. Lipid Imaging by Gold Cluster Time-of-Flight Secondary Ion Mass Spectrometry: Application to Duchenne Muscular Dystrophy. J. Lipid Res. 2005, 46, 1388-1395.
61. Touboul, D.; Kollmer, F.; Niehuis, E.; Brunelle, A.; Laprevote, O. Improvement of Biological Time-of-Flight-Secondary Ion Mass Spectrometry Imaging with a Bismuth Cluster Ion Source. J. Am. Soc. Mass Spectrom. 2005, 16, 1608-1618.

62. Takats, Z.; Wiseman, J. M.; Gologan, B.; Cooks, R. G. Mass Spectrometry Sampling under Ambient Conditions with Desorption Electrospray Ionization. Science 2004, 306, 471-473.

63. Sampson, J. S.; Hawkridge, A. M.; Muddiman, D. C. Generation and Detection of Multiply-Charged Peptides and Proteins by MatrixAssisted Laser Desorption Electrospray Ionization (MALDESI) Fourier Transform Ion Cyclotron Resonance Mass Spectrometry. J. Am. Soc. Mass Spectrom. 2006, 17, 1712-1716.

64. Sampson, J. S.; Muddiman, D. C. Atmospheric Pressure Infrared (10.6 Mu M) Laser Desorption Electrospray Ionization (Ir-Ldesi) Coupled to a LTO Fourier Transform Ion Cyclotron Resonance Mass Spectrometer. Rapid Commun. Mass Spectrom. 2009, 23, 1989-1992.

65. Brady, J. J.; Judge, E. J.; Levis, R. J. Mass Spectrometry of Intact Neutra Macromolecules Using Intense Non-Resonant Femtosecond Laser Vaporization with Electrospray Post-Ionization. Rapid Commun. Mass Spectrom. 2009, 23, 3151-3157.

66. Nemes, P.; Barton, A. A.; Li, Y.; Vertes, A. Ambient Molecular Imaging and Depth Profiling of Live Tissue by Infrared Laser Ablation Electrospray Ionization Mass Spectrometry. Anal. Chem. 2008, 80, 4575-4582.

67. Nemes, P.; Barton, A. A.; Vertes, A. Three-Dimensional Imaging of Metabolites in Tissues under Ambient Conditions by Laser Ablation Electrospray Ionization Mass Spectrometry. Anal. Chem. 2009, 81 6668-6675.

68. Costa, A. B.; Cooks, R. G. Simulated Splashes: Elucidating the Mechanism of Desorption Electrospray Ionization Mass Spectrometry. Chem. Phys. Lett. 2008, 464, 1-8.

69. Venter, A.; Sojka, P. E.; Cooks, R. G. Droplet Dynamics and Ionization Mechanisms in Desorption Electrospray Ionization Mass Spectrometry. Anal. Chem. 2006, 78, 8549-8555.

70. Dole, M.; Mack, L. L.; Hines, R. L. Molecular Beams of Macro-Ions J. Chem. Phys. 1968, 49, 2240-2250.

71. Iribarne, J. V.; Thomson, B. A. Evaporation of Small Ions from Charged Droplets. J. Chem. Phys. 1976, 64, 2287-2294.

72. Dill, A. L.; Ifa, D. R.; Manicke, N. E.; Zheng, O. Y.; Cooks, R. G. Mass Spectrometric Imaging of Lipids Using Desorption Electrospray Ionization. J. Chromatogr. B Anal. Technol. Biomed. Life Sci. 2009, 877, 2883-2889.

73. Esquenazi, E.; Dorrestein, P. C.; Gerwick, W. H. Probing Marine Natural Product Defenses with DESI-Imaging Mass Spectrometry. Proc. Natl. Acad. Sci. U.S.A. 2009, 106, 7269-7270.

74. Ifa, D. R.; Wiseman, J. M.; Song, Q. Y.; Cooks, R. G. Development of Capabilities for Imaging Mass Spectrometry under Ambient Conditions with Desorption Electrospray Ionization (DESI). Int. J. Mass Spectrom. 2007, 259, 8-15.

75. Kertesz, V.; Van Berkel, G. J. Improved Imaging Resolution in Desorption Electrospray Ionization Mass Spectrometry. Rapid Commun. Mass Spectrom. 2008, 22, 2639-2644.

76. Kertesz, V.; Van Berkel, G. J. Scanning and Surface Alignment Considerations in Chemical Imaging with Desorption Electrospray Mass Spectrometry. Anal. Chem. 2008, 80, 1027-1032.

77. Kertesz, V.; Van Berkel, G. J.; Vavrek, M.; Koeplinger, K. A.; Schneider, B. B.; Covey, T. R. Comparison of Drug Distribution Images from Whole-Body Thin Tissue Sections Obtained Using Desorption Electrospray Ionization Tandem Mass Spectrometry and Autoradiography. Anal. Chem. 2008, 80, 5168-5177.

78. Lane, A. L.; Nyadong, L.; Galhena, A. S.; Shearer, T. L.; Stout, E. P. Parry, R. M.; Kwasnik, M.; Wang, M. D.; Hay, M. E.; Fernandez, F. M. Kubanek, J. Desorption Electrospray Ionization Mass Spectrometry Reveals Surface-Mediated Antifungal Chemical Defense of a Tropical Seaweed. Proc. Natl. Acad. Sci. U.S.A. 2009, 106, 7314-7319.

79. Talaty, N.; Takats, Z.; Cooks, R. G. Rapid In Situ Detection of Alkaloids in Plant Tissue under Ambient Conditions Using Desorption Electrospray Ionization. Analyst 2005, 130, 1624-1633.

80. Wiseman, J. M.; Ifa, D. R.; Song, Q. Y.; Cooks, R. G. Tissue Imaging at Atmospheric Pressure Using Desorption Electrospray Ionization (DESI) Mass Spectrometry. Angew. Chem. Int. Ed. 2006, 45, 7188-7192.

81. Wiseman, J. M.; Ifa, D. R.; Venter, A.; Cooks, R. G. Ambient Molecular Imaging by Desorption Electrospray Ionization Mass Spectrometry. Nat. Protoc. 2008, 3, 517-524

82. Wiseman, J. M.; Ifa, D. R.; Zhu, Y. X.; Kissinger, C. B.; Manicke, N. E. Kissinger, P. T.; Cooks, R. G. Desorption Electrospray Ionization Mass Spectrometry: Imaging Drugs and Metabolites in Tissues. Proc. Natl. Acad. Sci. U.S.A. 2008, 105, 18120-18125

83. Wiseman, J. M.; Puolitaival, S. M.; Takats, Z.; Cooks, R. G.; Caprioli, R. M. Mass Spectrometric Profiling of Intact Biological Tissue by Using Desorption Electrospray Ionization. Angew. Chem. Int. Ed. 2005, 44 7094-7097.

84. Wu, C. P.; Ifa, D. R.; Manicke, N. E.; Cooks, R. G. Rapid, Direct Analysis of Cholesterol by Charge Labeling in Reactive Desorption Electrospray Ionization. Anal. Chem. 2009, 81, 7618-7624.

85. Manicke, N. E.; Nefliu, M.; Wu, C.; Woods, J. W.; Reiser, V.; Hendrickson, R. C.; Cooks, R. G. Imaging of Lipids in Atheroma by Desorption Electrospray Ionization Mass Spectrometry. Anal. Chem. 2009, 81, 8702-8707. 
86. Wu, C. P.; Ifa, D. R.; Manicke, N. E.; Cooks, R. G. Molecular Imaging of Adrenal Gland by Desorption Electrospray Ionization Mass Spectrometry. Analyst 2010, 135, 28-32.

87. Ifa, D. R.; Gumaelius, L. M.; Eberlin, L. S.; Manicke, N. E.; Cooks, R. G. Forensic Analysis of Inks by Imaging Desorption Electrospray Ionization (DESI) Mass Spectrometry. Analyst 2007, 132, 461-467.

88. Ifa, D. R.; Manicke, N. E.; Dill, A. L.; Cooks, G. Latent Fingerprint Chemical Imaging by Mass Spectrometry. Science 2008, 321, 805-805.

89. Monroe, E. B.; Annangudi, S. R.; Hatcher, N. G.; Gutstein, H. B.; Rubakhin, S. S.; Sweedler, J. V. Sims and MALDI MS Imaging of the Spinal Cord. Proteomics 2008, 8, 3746-3754.

90. Landgraf, R. R.; Conaway, M. C. P.; Garrett, T. I.; Stacpoole, P. W. Yost, R. A. Imaging of Lipids in Spinal Cord Using Intermediate Pressure Matrix-Assisted Laser Desorption-Linear Ion Trap/Orbitrap MS. Anal. Chem. 2009, 81, 8488-8495.

91. Manicke, N. E.; Kistler, T.; Ifa, D. R.; Cooks, R. G.; Ouyang, Z. High-Throughput Quantitative Analysis by Desorption Electrospray Ionization Mass Spectrometry. J. Am. Soc. Mass Spectrom. 2009, 20, 321-325.

92. Manicke, N. E.; Dill, A. L.; Ifa, D. R.; Cooks, R. G. High-Resolution Tissue Imaging on an Orbitrap Mass Spectrometer by Desorption Electrospray Ionization Mass Spectrometry. J. Mass Spectrom. 2010, 45, 223-226.

93. Manicke, N. E.; Wiseman, J. M.; Ifa, D. R.; Cooks, R. G. Desorption Electrospray Ionization (DESI) Mass Spectrometry and Tandem Mass Spectrometry (Ms/Ms) of Phospholipids and Sphingolipids: Ionization, Adduct Formation, and Fragmentation. J. Am. Soc. Mass Spectrom. 2008, 19, 531-543.

94. Pulfer, M.; Murphy, R. C. Electrospray Mass Spectrometry of Phospholipids. Mass Spectrom. Rev. 2003, 22, 332-364.

95. Kayganich, K. A.; Murphy, R. C. Fast-Atom-Bombardment Tandem Mass-Spectrometric Identification of Diacyl, Alkylacyl, and Alk-1Enylacyl Molecular-Species of Glycerophosphoethanolamine in $\mathrm{Hu}-$ man Polymorphonuclear Leukocytes. Anal. Chem. 1992, 64, 2965-2971.

96. Hsu, F. F.; Turk, J. Characterization of Phosphatidylethanolamine as a Lithiated Adduct by Triple Quadrupole Tandem Mass Spectrometry with Electrospray Ionization. J. Mass Spectrom. 2000, 35, 596-606.

97. Hsu, F. F.; Turk, J. Charge-Remote and Charge-Driven Fragmentation Processes in Diacyl Glycerophosphoethanolamine Upon Low-Energy Collisional Activation: A Mechanistic Proposal. J. Am. Soc. Mass Spectrom. 2000, 11, 892-899.

98. Cabrera, G. M. Murga, M. L. F. De Valdez, G. F. Seldes, A. M. Direct Analysis by Electrospray Ionization Tandem Mass Spectrometry of Mixtures of Phosphatidyldiacylglycerols from Lactobacillus. J. Mass Spectrom. 2000, 35, 1452-1459.

99. Hsu, F. F.; Turk, J. Structural Characterization of Triacylglycerols as Lithiated Adducts by Electrospray Ionization Mass Spectrometry Using Low-Energy Collisionally Activated Dissociation on a Triple Stage Quadrupole Instrument. J. Am. Soc. Mass Spectrom. 1999, 10, 587-599.

100. Hsu, F. F. Turk, J. Studies on Phosphatidylglycerol with Triple Quadrupole Tandem Mass Spectrometry with Electrospray Ionization: Fragmentation Processes and Structural Characterization. J. Am. Soc. Mass Spectrom. 2001, 12, 1036-1043.

101. Hsu, F. F.; Turk, J. Characterization of Phosphatidylinositol, Phosphatidylinositol-4-Phosphate, and Phosphatidylinositol-4,5-
Bisphosphate by Electrospray Ionization Tandem Mass Spectrometry: A Mechanistic Study. I. Am. Soc. Mass Spectrom. 2000, 11, 986-999.

102. Hsu, F. F.; Bohrer, A.; Turk, J. Electrospray Ionization Tandem Mass Spectrometric Analysis of Sulfatide. Determination of Fragmentation Patterns and Characterization of Molecular Species Expressed in Brain and in Pancreatic Islets. Biochim. Biophys. Acta 1998, 1392, 202-216.

103. Hsu, F. F.; Turk, J. Studies on Sulfatides by Quadrupole Ion-Trap Mass Spectrometry with Electrospray Ionization: Structural Characterization and the Fragmentation Processes that Include an Unusual Internal Galactose Residue Loss and the Classical Charge-Remote Fragmentation. J. Am. Soc. Mass Spectrom. 2004, 15, 536-546.

104. Murphy, R. C.; Harrison, K. A. Fast-Atom-Bombardment MassSpectrometry of Phospholipids. Mass Spectrom. Rev. 1994, 13, 57-75.

105. Al-Saad, K. A.; Siems, W. F.; Hill, H. H.; Zabrouskov, V.; Knowles, N. R. Structural Analysis of Phosphatidylcholines by Post-Source Decay Matrix-Assisted Laser Desorption/Ionization Time-of-Flight Mass Spectrometry. J. Am. Soc. Mass Spectrom. 2003, 14, 373-382.

106. Chilton, F. H.; Murphy, R. C. Fast-Atom-Bombardment Analysis of Arachidonic Acid-Containing Phosphatidylcholine Molecular-Species. Biomed. Environ. Mass Spectrom. 1986, 13, 71-76.

107. Domingues, P.; Domingues, M. R. M.; Amado, F. M. L.; Ferrer-Correia A. J. Characterization of Sodiated Glycerol Phosphatidylcholine Phospholipids by Mass Spectrometry. Rapid Commun. Mass Spectrom. 2001, $15,799-804$

108. Han, X. L.; Gross, R. W. Structural Determination of Picomole Amounts of Phospholipids Via Electrospray Ionization Tandem Mass Spectrometry. J. Am. Soc. Mass Spectrom. 1995, 6, 1202-1210.

109. Ho, Y. P.; Huang, P. C. A Novel Structural Analysis of Glycerophosphocholines as TFA/K+ Adducts by Electrospray Ionization Ion Trap Tandem Mass Spectrometry. Rapid Commun. Mass Spectrom. 2002, 16, 1582-1589.

110. Hsu, F. F.; Bohrer, A.; Turk, J. Formation of Lithiated Adducts of Glycerophosphocholine Lipids Facilitates Their Identification by Electrospray Ionization Tandem Mass Spectrometry. J. Am. Soc. Mass Spectrom. 1998, 9, 516-526.

111. Hsu, F. F.; Turk, J. Structural Determination of Sphingomyelin by Tandem Mass Spectrometry with Electrospray Ionization. J. Am. Soc Mass Spectrom. 2000, 11, 437-449.

112. Rujoi, M.; Estrada, R.; Yappert, M. C. In Situ MALDI-TOF MS Regional Analysis of Neutral Phospholipids in Lens Tissue. Anal. Chem. 2004, 76 , 1657-1663.

113. Estrada, R.; Yappert, M. C. Alternative Approaches for the Detection of Various Phospholipid Classes by Matrix-Assisted Laser Desorption/ Ionization Time-of-Flight Mass Spectrometry. J. Mass Spectrom. 2004, $39,412-422$

114. Petkovic, M.; Schiller, J.; Muller, M.; Benard, S.; Reichl, S.; Arnold, K. Arnhold, J. Detection of Individual Phospholipids in Lipid Mixtures by Matrix-Assisted Laser Desorption/Ionization Time-of-Flight Mass Spectrometry: Phosphatidylcholine Prevents the Detection of Further Species. Anal. Biochem. 2001, 289, 202-216.

115. Conklin, S. M.; Gianaros, P. J.; Brown, S. M.; Yao, J. K.; Hariri, A. R. Manuck, S. B.; Muldoon, M. F. Long-Chain Omega-3 Fatty Acid Intake Is Associated Positively with Corticolimbic Gray Matter Volume in Healthy Adults. Neurosci. Lett. 2007, 421, 209-212. 